\title{
KEPASTIAN HUKUM SURAT KETERANGAN WARIS SEBAGAI PERSYARATAN PENGAMBILAN JAMINAN KREDIT
}

\author{
Aden Ahmad, Sihabudin \& Siti Hamidah \\ Program Studi Magister Kenotariatan, Fakultas Hukum Universitas Brawijaya \\ Jalan Abdul Muis 52-56A, Jakarta, 10160, \\ Email: aden_mifa@yahoo.com
}

\begin{abstract}
The purpose of writing is to analyze the legal certainty of inheritance certificate made according to the classification of the population as a requirement to collect credit guarantees. The method used in writing is a qualitative method with a normative approach. The existence of the provisions of classification of the population as the provisions of Article 131 and 163 Indische Staatregeling can not provide legal certainty in the manufacture of inheritance information used as a condition of collateral credit collection, because in practice there is a bank requesting an inheritance certificate must be made by Notary, although the concerned group indigenous. Actually, Article 15 paragraph (1) of the Notary's Office Law 2014 does not clearly mention the authority of Notary to make an inheritance certificate, but the bank prefers certificate of inheritance must be made by Notary, in consideration because the certificate of inheritance made by Notary has more strong evidentiary power. This is because every deed made by a Notary has external, formal and material authentication power. It should be noted that after Indonesia Merdeka, the practice of making an inheritance certificate based on occupation class need not exist anymore, because it is contradictory to Law Number 40 Year 2008, because it is a criminal act as well as racist, and violates the principles of Human Rights. Thus, the rule of law in the production of evidence as heirs that still have to be based on ethnicity and the institutions that make it different must be immediately terminated, in addition there is no legal consequence whatsoever with the existence of the heterogeneity of the evidence of this ethnic heir.
\end{abstract}

Keywords: Legal certainty, Inheritance certificate, Population group, Collection of credit guarantee.

\begin{abstract}
Abstrak
Tujuan penulisan adalah untuk menganalisis kepastian hukum surat keterangan waris yang dibuat menurut penggolongan penduduk sebagai persyaratan pengambilan jaminan kredit. Metode yang digunakan dalam penulisan adalah metode kualitatif dengan pendekatan normatif. Adanya ketentuan penggolongan penduduk seperti ketentuan Pasal 131 dan 163 Indische Staatregeling tidak dapat memberikan kepastian hukum dalam pembuatan keterangan waris yang digunakan sebagai syarat pengambilan jaminan kredit, karena dalam praktiknya ada pihak bank yang meminta surat keterangan waris harus dibuat oleh Notaris, walaupun yang bersangkutan termasuk golongan pribumi. Sebenarnya Pasal 15 ayat (1) UUJN 2014 tidak secara jelas menyebutkan kewenangan Notaris untuk membuat surat keterangan waris, namun pihak bank lebih memilih surat keterangan waris harus dibuat oleh Notaris, dengan pertimbangan karena surat keterangan waris yang dibuat oleh Notaris lebih memiliki kekuatan pembuktian yang kuat. Hal ini karena setiap akta yang dibuat oleh Notaris memiliki kekuatan pembuktian lahiriah, formal dan material. Perlu diperhatikan bahwa setelah Indonesia Merdeka, mestinya praktik pembuatan surat keterangan waris berdasarkan golongan pendudukan tidak perlu ada lagi, karena hal tersebut bertentangan dengan UU Nomor 40 Tahun 2008, karena hal tersebut merupakan tindakan dikriminatif sekaligus rasialis, dan melanggar prinsip-prinsip Hak Azasi Manusia. Dengan demikian, aturan hukum dalam pembuatan bukti sebagai ahli waris yang masih harus berdasarkan etnis dan institusi yang membuatnya berbeda harus segera diakhiri, di samping itu tidak ada akibat hukum apapun dengan adanya pembedaan bukti ahli waris berdasarkan etnis ini.
\end{abstract}

Kata kunci: Kepastian hukum, Surat keterangan waris, Golongan penduduk, Pengambilan jaminan kredit 


\section{Pendahuluan}

Pemberian utang atau kredit oleh kreditor dalam kedudukannya sebagai orang perseorangan maupun badan hukum kepada debitor, sudah lazim terjadi dalam kehidupan masyarakat. Pada jaman sekarang ini jarang menemukan seorang pengusaha yang tidak menggunakan fasilitas utang (pinjaman atau kredit) dalam bentuk utang jangka pendek, jangka menengah maupun utang jangka panjang.

Bank dan lembaga keuangan (bukan bank) lainnya dalam menyalurkan dana pinjaman kepada masyarakat akan mendapatkan konpensasi dalam bentuk bunga pinjaman, provisi dan pendapatan lainnya, yangmana kesemuanya itu merupakan pendapatan. Karena dana yang disalurkan adalah dana masyarakat, maka didalam menyalurkan dananya kepada masyarakat selalu menggunakan prinsip kehati-hatiannya.

Pada umumnya bank atau lembaga bukan bank laninya tidak akan berani memberikan kredit yang sumbernya dari dana masyarakat kepada masyarakat yang membutuhkannya tanpa adanya jaminan (collateral). Adapun peranan penting dari jaminan tersebut adalah guna memberikan hak dan kekuasaan kepada bank selaku kreditor untuk mendapatkan pelunasan dengan barang-barang jaminan tersebut, apabila pihak peminjam (debitor) cidera janji tidak membayar kembali hutangnya pada waktu yang telah ditetapkan dalam perjanjian. Hal itu mungkin saja terjadi, karena tidak semua nasabah yang mendapatkan pinjaman dari bank dapat menggunakan dananya dengan benar dan berhasil.
Apabila kreditor dan debitor telah membuat perjanjian, maka lahirlah hak dan kewajiban diantara kedua belah pihak. Kreditor berkewajiban menyerahkan uang yang diperjanjikan dengan hak untuk menerima kembali uang tersebut dari debitor tepat pada waktunya disertai bunga dan biaya. ${ }^{1}$

Hak dan kewajiban debitor dalam perjanjian pinjam meminjam uang atau perjanjian kredit bersifat timbal balik dengan hak dan kewajiban kreditor. Bagi Perbankan pemberian kredit kepada dunia usaha selalu mengandung resiko, namun selama kedua belah pihak melaksanakan hak dan kewajibannya dengan baik maka tidak akan terjadi perselisihan. Oleh karenanya untuk mengamankan pengembalian dana yang disalurkan perlu dilakukan pengikatan jaminan. Kitab Undang-Undang Hukum Perdata (KUHPerdata) telah memberikan pengaman kepada kreditor dalam menyalurkan kredit kepada debitor, yakni dengan memberikan jaminan khusus Jaminan khusus berupa kebendaan yang diminta oleh bank dalam penyaluran kredit merupakan realisasi dari prinsip kehati-hatian perbankan (Prudential banking principle). ${ }^{2}$

Penyerahan jaminan oleh debitor kepada kreditor (bank) merupakan bentuk pemberian jaminan debitor kepada kreditor bahwa debitor sanggup melunasi utangnya kepada kreditor, dan merupakan upaya perlindungan hukum bagi kreditor apabila debitor cidera janji tidak melunasi utang

Ahmad Yani \&Gunawan Wijaya, Seri Hukum Bisnis./Jaminan Fidusia, Radja Grailndo Perkasa, Jakarta, 2000, hlm 2.

2 Muhamad Djumhana, Hukum Perbankan di Indonesia, Citra Aditya Bakti, Bandung, 1993, hlm. 14. 
tersebut pada waktunya, sehingga kreditor dapat menggunakan jaminan yang diberikan debitor tersebut sebagai alternatif lain sebagai sumber pelunasan utangnya.

Sebagaimana dijelaskan dalam Pasal 1131 KUH Perdata yakni, sebagai berikut: "Segala kebendaan si berutang, baik yang bergerak maupun yang tak bergerak, baik yang sudah ada maupun yang baru akan ada di kemudian hari, menjadi tanggungan untuk segala perikatan perseorangan". Apabila si berhutang meninggal dunia, maka tanggung jawab terkait dengan perjanjian utang tersebut berpindah kepada ahli warisnya.

Terkait dengan waris tidak dapat dilepaskan dari persoalan bukti sebagai ahli waris. Bukti sebagai ahli waris yang dimaksud dalam hal ini ialah keterangan atau surat waris. Keberadaan ahli waris sangat penting dalam hal pewarisan, dalam praktik untuk membuktikan kedudukan seseorang sebagai ahli waris diperlukan suatu dokumen yang berkedudukan sebagai alat bukti yang dapat membuktikan kedudukan tersebut. Dalam kontek hukum perdata, termasuk hukum waris, bukti surat akan menjadi bukti yang penting dan utama dibandingkan alat bukti lain.

Surat keterangan waris tersebut juga dapat digunakan untuk alas hak bagi seseorang (ahli waris) untuk mengurus hak-haknya dalam suatu perjanjian kredit perbankan, termasuk pengambilan jaminan kredit, yang telah dulu pernah digunakan oleh orang tua atau saudaranya untuk mengambil kredit pada suatu bank.

Dalam praktinya Surat Keterangan Waris dapat berupa surat keterangan waris di bawah tangan atau surat keterangan dalam bentuk akta otentik seperti yang dibuat oleh Notaris. Keterangan waris bawah tangan biasanya dibuat oleh RT, RW, Kelurahan hingga Kecamatan, sedangkan surat keterangan waris dalam bentuk otentik dapat dibuat oleh Notaris.

Di Indonesia, pemberian Surat Keterangan Waris diatur secara berbeda berdasarkan golongan penduduk. Hal ini seperti surat Mahkamah Agung Republik Indonesia tanggal 8 Mei 1991 Nomor MA/Kumdil/171/V/K/1991 yang ditujukan kepada Mahkamah Agung Republik Indonesia tanggal 25 Maret 1991 Nomor KMA/041//II/1991, telah menunjuk Surat Edaran tanggal 20 Desember 1969 Nomor Dpt/12/63/12/69 yang diterbitkan oleh Direktorat Jenderal Agraria Direktorat Pendaftaran Tanah (Kadaster) di Jakarta, yang menyatakan bahwa guna keseragaman dan berpokok pangkal dari penggolangan penduduk yang pernah dikenal sejak sebelum kemerdekaan, hendaknya keterangan hak waris untuk warga negara Indonesia juga diterbitkan berdasarkan penggolangan tersebut.

Pembuktian kedudukan seseorang sebagai ahli waris bagi golongan Eropa, Cina atau Tionghoa, Timur Asing (kecuali orang Arab yang beragama Islam), digunakan Surat Keterangan Waris yang dibuat oleh Notaris, dalam bentuk Surat Keterangan. Golongan Timur Asing (bukan Cina/Tionghoa), selama ini pembuktian mereka sebagai ahli waris berdasarkan Surat Keterangan Waris yang dibuat oleh Balai Harta Peninggalan (selanjutnya disebut BHP). Golongan Pribumi (Bumiputera), selama ini pembuktian mereka sebagai ahli waris berdasarkan Surat Keterangan Waris yang dibuat di bawah tangan, bermeterai, 
oleh para ahli waris sendiri dan diketahui atau dibenarkan oleh Lurah dan Camat sesuai dengan tempat tinggal terakhir pewaris. Golongan Eropa, Cina atau Tionghoa, Timur Asing (kecuali orang Arab yang beragama Islam), selama ini pembuktian sebagai ahli waris berdasarkan Surat Keterangan Waris yang dibuat oleh Notaris, dalam bentuk Surat Keterangan.

Walaupun ada ketentuan bagi penduduk pribumi cukup menggunakan Surat Keterangan Waris yang dibuat di bawah tangan, namun kenyataannya seringkali pihak yang berkepentingan meminta Surat Keterangan Waris tersebut dibuat oleh Notaris. Hal ini seperti ketentuan yang berlaku di Bank CIMB Niaga bahwa persyaratan pengambilan jaminan lunas kredit diatur sebagai berikut:

1) Debitur langsung: (a) asli KTP, atau (2) asli passport dan KITAP/KITAS asli (WNA);

2) Surat Kuasi Notaril: (a) asli Surat Kuasa Akta Notaril; (b) asli KTP/passport pemberi kuasa atau copy legalisir notaris; (c) asli KTP/passport penerima kuasa;

3) Surat Kuasa Debitur Domisili di Luar Negeri: (a) asli Surat Kuasa yang dibuat di hadapan Public Notary; (b) asli Surat Kuasa legalisir dari Kedusbes/Konjen; (c) copy KTP/passport pemberi kuasa legalisir Kedusbes/Konjen/Notaris; $\quad$ (d) asli KTP/passport pemberi kuasa;

4) Debitur meninggal: (a) asli KTP/passport debitur (jika ada); (b) asli KTP/passport para ahli waris; (c) asli Kartu Keluarga; (d) asli KITAP/KITAS (WNA); (e) asli Akta Kelahiran; (f) asli Surat Kematian debitur; (g) asli Surak
Nikah; (h) asli Surat Cerai (kondisi khusus); (i) asli Akta Waris Debitur; (j) asli Surat Kuasa Ahli Waris (Notaril); (k) asli Surat Pernyataan Ahli Waris (standar bank).

Sesuai ketentuan angka 4 huruf (j) di atas bahwa Surat Kuasa Ahlli Waris atau Surat Keterangan Waris untuk mengambil jaminan kredit di Bank CIMB Niaga harus dibuat oleh Notaris. Praktik seperti ini, dilihat dari ketentuan hukum yang berlaku di Indonesia jelas bertentangan dengan surat Mahkamah Agung Republik Indonesia tanggal 8 Mei 1991 Nomor MA/Kumdil/171/V/K/1991 tentang Surat Keterangan Waris harus diterbitkan berdasarkan penggolangan penduduk, untuk golongan pribumi cukup dibuat oleh RT, RW, Kelurahan hingga Kecamatan.

Adanya perbedaan penafsiran praktik hukum seperti di atas, menandakan telah terjadi ketidakpastian hukum dalam dunia perbankan terkait dengan Surat Keterangan Waris sebagai persyaratan pengambilan jaminan kredit oleh ahli waris debitur. Pihak bank meminta Surat Keterangan Waris dibuat oleh Notaris, karena bank menginginkan surat tersebut berupa akta otentik (notariil) untuk mencegah risiko sebagai bentuk sikap kehati-hatian bank dalam upaya self regulatory banking dan prudential banking principle.

Surat Keterangan Waris yang dibuat oleh Notaris berlangsung hingga saat telah berlakunya Undang-Undang Jabatan Notaris (UUJN). UUJN merupakan peraturan perundang-undangan utama yang mengatur mengenai Jabatan Notaris. UUJN menentukan sejumlah kewenangan Notaris, dalam Pasal 15 ayat (1) UUJN diatur kewenangan umum Notaris sebagai berikut: Notaris berwenang 
membuat Akta autentik mengenai semua perbuatan, perjanjian, dan penetapan yang diharuskan oleh peraturan perundang-undangan dan/atau yang dikehendaki oleh yang berkepentingan untuk dinyatakan dalam Akta autentik, menjamin kepastian tanggal pembuatan Akta, menyimpan Akta, memberikan grosse, salinan dan kutipan Akta, semuanya itu sepanjang pembuatan Akta itu tidak juga ditugaskan atau dikecualikan kepada pejabat lain atau orang lain yang ditetapkan oleh undangundang.

Kewenangan umum Notaris sebagaimana dimaksud dalam Pasal 15 ayat (1) UUJN, dalam Pasal 15 ayat (2) UUJN ditentukan kewenangan lain dari Notaris sebagai berikut :

Selain kewenangan sebagaimana dimaksud pada ayat (1), Notaris berwenang pula:

a) mengesahkan tanda tangan dan menetapkan kepastian tanggal surat di bawah tangan dengan mendaftar dalam buku khusus;

b) membukukan surat di bawah tangan dengan mendaftar dalam buku khusus;

c) membuat kopi dari asli surat di bawah tangan berupa salinan yang memuat uraian sebagaimana ditulis dan digambarkan dalam surat yang bersangkutan;

d) melakukan pengesahan kecocokan fotokopi dengan surat aslinya;

e) memberikan penyuluhan hukum sehubungan dengan pembuatan Akta;

f) membuat Akta yang berkaitan dengan pertanahan; atau

g) membuat Akta risalah lelang.
Pasal 15 ayat (1) dan (2) UUJN jika dicermati tidak mengatur secara eksplisit mengenai kewenangan Notaris untuk membuat Surat Keterangan Waris, termasuk pula mengenai sifat dari Surat Keterangan Waris, tidak terdapat penjelasan apakah termasuk sebagai akta otentik ataukah surat di bawah tangan.

Berkaitan dengan latar belakang, kewenangan Notaris dalam membuat Surat Kewenangan Waris, dan fungsi Surat Kewenangan Waris sebagai alat bukti, penulis ingin meneliti dengan mengambil judul "Kepastian Hukum Surat Keterangan Waris Sebagai Persyaratan Pengambilan Jaminan Kredit".

Berdasarkan latar belakang di atas, maka permasalalahan yang diangkat pada tulisan ini dapat dirumuskan sebagai berikut: Apakah dengan adanya penggolongan penduduk dapat memberikan kepastian hukum dalam pembuatan keterangan waris yang digunakan sebagai syarat pengambilan jaminan kredit?

Metode yang digunakan dalam penulisan ini adalah metode kualitatif dengan pendekatan normatif. Metode penelitian kualitatif adalah metode penelitian yang digunakan untuk meneliti pada kondisi objek yang alamiah, dimana peneliti adalah sebagai intsrumen kunci, teknik pengumpulan data dilakukan secara trianggulasi (gabungan), analisis data bersifat induktif, dan hasil penelitian kualitatif lebih menekankan makna dari pada generalisasi. ${ }^{3}$ Sedangkan pendekatan normatif adalah penelitian yang mengkaji kepustakaan atau studi dokumen, karena penelitian ini lebih banyak akan dilakukan melalui studi kepustakaan atau lebih

3 Sugiyono, Memahami Penelitian Kualitatif, Alfabeta, Bandung, 2010, hlm. 1. 
24 Aden Ahmad dkk, Kepastian Hukum Surat Keterangan Waris.....

dikenal dengan studi pada data sekunder. ${ }^{4}$

\section{Pembahasan}

\subsection{Kekuatan Pembuktian Keterangan Waris Berdasarkan Penggolongan Penduduk untuk Pengambilan Jaminan Kredit}

Surat keterangan ahli waris berfungsi untuk membuktikan siapa-siapa saja yang berhak atas ahli waris yang ditinggalkan oleh seseorang yang telah meninggal (pewaris) yang menjadi dasar atas pembagian harta warisan baik atas siapa yang berhak dan / atau berapa jumlah bagian yang berhak dimiliki oleh ahli waris baik berdasarkan legitime portie dan/atau berdasarkan wasiat. ${ }^{5}$ Dalam praktek pembuatan surat keterangan ahli waris dilakukan oleh pejabat yang berbeda yang didasarkan pada golongan penduduk. Ada tiga pejabat yang berwenang membuat surat keterangan ahli waris, yakni notaris bagi Golongan Tionghoa, Balai Harta Peninggalan (BHP) bagi golongan Timur Asing non Tionghoa atau dibuat sendiri oleh ahli waris di atas kertas dengan disaksikan oleh Lurah/Kepala Desa dan dikuatkan oleh Camat bagi golongan WNI Bumiputera.

Di dalam Peraturan Menteri Agraria / Kepala Badan Pertanahan Nasional No.3 Tahun 1997 tentang Ketentuan Pelaksanaan Peraturan Pemerintah No. 24 Tahun 1997 tentang Pendaftaran Tanah ada termuat ketentuan yang dapat dijadikan pedoman bagi pembuatan Surat Keterangan Ahli Waris namun khusus yang berhubungan dengan barang tidak bergerak berupa tanah yang telah terdaftar atau bersertipikat. Namun secara umum ketentuan peraturan perundang-undangan yang mengatur tentang kewenangan pejabat dan tata cara serta bentuk pembuatan dan format Surat Keterangan Ahli Waris bagi golongan Bumiputera belum ada sama sekali.

Pasal 111 ayat (1) huruf $c$ Peraturan Menteri Agraria / Kepala Badan Pertanahan Nasional No.3 Tahun 1997 tentang Ketentuan Pelaksanaan Peraturan Pemerintah No. 24 Tahun 1997 tentang Pendaftaran Tanah yang memuat ketentuan pedoman pembuatan Surat Keterangan Ahli Waris dalam hal pelaksanaan pengalihan hak atas tanah yang menyebutkan bahwa, Surat tanda bukti sebagai ahli waris dapat berupa :

1. Wasiat dari pewaris

2. Putusan pengadilan

3. Penetapan hakim / ketua pengadilan

4. Bagi warga negara Indonesia penduduk asli (pribumi), surat keterangan ahli waris yang dibuat oleh para ahli waris dengan disaksikan oleh 2 (dua) orang saksi dan dikuatkan oleh kepala desa / kelurahan dan camat tempat tinggal pewaris pada waktu meninggal dunia. Bagi warga negara Indonesia keturunan Tionghoa akta keterangan hak mewaris dibuat oleh notaris dan bagi warga negara Indonesia keturunan timur asing lainnya surat keterangan waris dari Balai Harta Peninggalan. ${ }^{6}$

4 Soerjono Soekanto dan Sri Mamudji, Penelitian Hukum Normatif, Suatu Tinjauan Singkat, Raja Grafindo Persada, Jakarta, 2006, hlm. $13-14$

5 Herlien Budiono, Kumpulan Tulisan Hukum Perdata di Bidang Kenotariatan, Buku Kedua, Citra Aditya Bakti, Bandung, 2013, hlm. 84

6 Zainuddin Ali, Pelaksanaan Surat Keterangan Hak Waris bagi Golongan Penduduk di Indonesia, Sinar Grafika, Jakarta, 2011. hlm.39 
1) Kekuatan Pembuktian Surat Keterangan Waris yang Dibuat Notaris

Akta-akta yang dibuat oleh ataupun dihadapan notaris adalah akta otentik, sebagaimana keotentikan suatu akta diatur dalam pasal 1868 KUHPerdata.

Surat keterangan waris untuk golongan penduduk Cina dalam Pasal 111 Ayat (1) huruf $c$ angka 4 Peraturan Menteri Negara Agraria/Kepala Badan Pertanahan Nasional Nomor 3 Tahun 1997 tentang Pelaksanaan Peraturan Pemerintah Nomor 24 Tahun 1997 tentang Pendaftaran Tanah, dibuat oleh notaris dalam bentuk akta.

Tidak ada keterangan lebih lanjut mengenai bagaimana bentuk akta keterangan waris harus dibuat, mengingat notaris membuat akta otentik sebagaimana bentuknya telah ditentukan oleh Undang-Undang Jabatan Notaris, dan dikenal dua macam bentuk akta yaitu akta partij dan akta relaas.

a. Akta Partij (Akta Para Penghadap), yaitu akta yang dibuat dihadapan pejabat umum, yang berisi uraian atau keterangan, pernyataan para pihak yang diberikan atau yang diceritakan dihadapan pejabat umum.

b. Akta Relaas (Akta Pejabat), yaitu akta yang dibuat oleh pejabat umum disebut juga Akta Berita Acara yang isinya berupa uraian dari pejabat umum atas permintaan para pihak, agar perbuatan atau tindakan para pihak yang dilakukan di hadapan pejabat umum tersebut dituangkan dalam akta otentik. ${ }^{7}$

Notaris membuat surat keterangan waris berdasarkan kebiasaan dari notaris terdahulu dan penunjukannya dalam Surat Edaran Departemen
Dalam Negeri Direktorat Jenderal Agraria tanggal 20 Desember 1969 Nomor Dpt/12/63/12/69 tentang Surat Keterangan Warisan dan Pembuktian Kewarganegaraan.

Meskipun membuat surat keterangan waris telah menjadi kebiasaan dari para notaris, namun masih terdapat perbedaan pendapat mengenai bagaimana bentuk akta keterangan waris. Habib Adjie menyarankan agar notaris membuat akta keterangan waris dalam bentuk akta pihak/partij acta: "Sesuai dengan wewenang yang dimiliki oleh notaris, yaitu untuk membuat akta otentik dengan bingkai Pasal 15 ayat (1), Pasal 38 dan Pasal 58 ayat (2) UUJN serta Pasal 1868 KUHPerdata, yaitu dengan membuatkan Akta Keterangan Sebagai Ahli Waris dalam bentuk Akta Pihak."

Namun juga terdapat pendapat yang menyarankan agar notaris tidak membuat surat keterangan waris dalam bentuk akta pihak/partij acta, mengingat apabila dibuat dalam bentuk akta pihak dirasa tidak sesuai, dikarenakan dalam akta pihak terdapat kehendak dari para pihak yang dituangkan dalam isi akta. Mengingat dalam surat keterangan waris terdapat pembagian harta waris yang dibuat oleh notaris berdasarkan pengetahuannya mengenai hukum waris BW.

Tan thong Kie berpendapat apabila surat keterangan waris dibuat dalam bentuk akta dibawah tangan: "siapakah para penghadap dan apakah akta tersebut dibuat menurut PJN? Kalau demikian,

7 Herlien Budiono, Kumpulan Tulisan Hukum Perdata di Bidang Kenotariatan, PT. Citra Aditya Bakti, Bandung, 2013, hlm. 267-268 
26 Aden Ahmad dkk, Kepastian Hukum Surat Keterangan Waris.....

harus ada (para) penghadap, semua angka harus ditulis dengan dengan huruf, semua pengubahan harus diparaf, dan sebagainya."8 Kesimpulan apakah yang dapat kita ambil dari arti in originali dalam Pasal 14 Grootboekwet? Menurut Tan thong Kie, artinya tidak lain dari "dibawah tangan", yaitu tanpa minuta dan tanpa penghadap. ${ }^{9}$

Namun Tan Thong Kie juga tidak menyalahkan apabila surat keterangan waris dibuat dalam bentuk akta notaris, beliau mengatakan dalam bukunya: "kita dapat mengambil kesimpulan bahwa keterangan waris juga dapat dibuat dalam bentuk akta notaris. Dengan kata lain, akta itu dapat juga dibuat dengan hadirnya penghadap dan sesuai dengan aturan-aturan dalam PJN, antara lain masuk repertorium."10 Cara kerja ini memudahkan pemegang protokol membuat salinan, seandainya dikemudian hari untuk itu ada permintaan suatu keterangan waris yang dibuat olehnya.Memang akta yang dibuat demikian agak aneh dan pernah dicela karena seakan-akan notaris menjadi penghadap dalam aktanya sendiri."11

Pejabat umum yang ditunjuk berdasarkan undang-undang dalam hal ini adalah UUJN Nomor 30 Tahun 2004 jo UUJN Nomor 2 Tahun 2014 sebagai salah satu pejabat umum yang berwenang membuat akta autentik hampir diseluruh perbuatan hukum sebagaimana juga termuat di dalam ketentuan Pasal 15 UUJN Nomor 30 Tahun 2004 jo UUJN Nomor 2 Tahun 2014. Suatu akta autentik mempunyai kekuatan pembuktian lahiriah, formal dan material. ${ }^{12}$
Kekuatan pembuktian lahiriah adalah suatu kekuatan yang membuktikan bahwa akta autentik tersebut kehadirannya atau kelahirannya telah sesuai sebagaimana ditentukan dalam peraturan perundang-undangan yang mengaturnya. Kekuatan pembuktian formal mengandung arti bahwa apa saja yang dinyatakan dalam suatu akta autentik adalah benar sepanjang tidak dapat dibuktikan bahwa hal tersebut tidak benar. Kekuatan pembuktian material adalah memberikan kepastian terhadap peristiwa hukum, apa yang diterangkan dengan akta tersebut adalah benar.

Akta autentik yang dibuat oleh Notaris mempunyai kekuatan pembuktian yang sempurna sehingga tidak perlu dibuktikan atau ditambah dengan alat bukti lainnya, dan jika ada orang/pihak yang menilai atau menyatakan bahwa akta tersebut tidak benar, maka orang/pihak yang menilai atau menyatakan tidak benar tersebut wajib membuktikan penilaian atau pernyataanya sesuai aturan hukum yang berlaku. ${ }^{13}$

Kekuatan pembuktian akta notaris berhubungan dengan sifat publik dalam jabatan notaris. Sepanjang suatu akta notaris tidak dapat dibuktikan ketidak-benarannya, maka akta tersebut merupakan akta autentik yang memuat keterangan yang sebenarnya dari pihak-pihak yang menyatakan keterangannya di dalam akta autentik tersebut dan hal tersebut didukung oleh dokumen-dokumen yang sah dan saksi-saksi yang dapat dipertanggungjawabkan sesuai ketentuan peraturan perundangundangan yang berlaku.

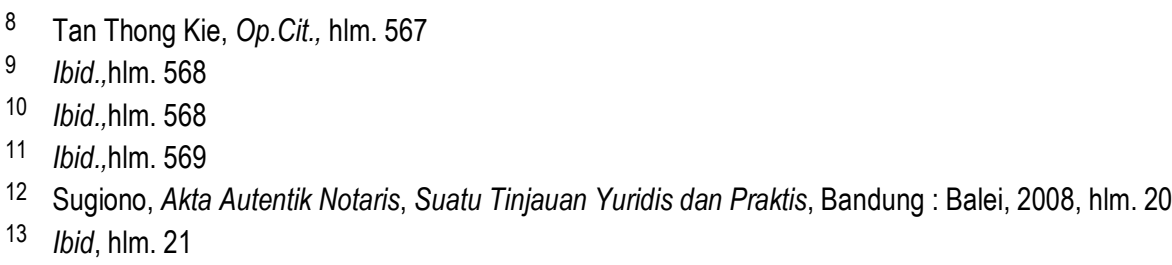


Notaris sebagai pejabat publik mempunyai kewenangan dengan pengecualian, dimana akta autentik yang dihasilkan mempunyai arti yang lebih penting tidak hanya sekedar sebagai alat bukti bila terjadi sengketa, namun akta autentik dapat juga digunakan sebagai pedoman bagi para pihak yang bersengketa.

Akta notaris berisi keterangan pernyataan para pihak dan dibuat atas kehendak atau permintaan para pihak, dan notaris membuatnya dalam bentuk yang sudah ditentukan menurut undang-undang, serta notaris bukan pihak dalam akta tersebut, pencantuman nama notaris dalam akta karena perintah undang-undang. ${ }^{14}$ Dengan demikian dapat dikatakan akta notaris sebagai suatu akta autentik harus dinilai dengan asas praduga sah (vermoeden van rechtmaigheid) atau presumptio iustae causa. Asas ini dapat dipergunakan untuk menilai akta notaris, yaitu akta notaris harus dianggap sah sampai ada pihak yang menyatakan akta tersebut tidak sah. Untuk menyatakan atau menilai akta tersebut tidak sah harus dengan gugatan ke pengadilan umum. Selama dan sepanjang gugatan berjalan sampai dengan ada keputusan pengadilan yang mempunyai kekuatan hukum tetap, maka akta notaris tetap sah dan mengikat para pihak atau siapa saja yang berkepentingan dengan akta tersebut.

2) Kekuatan Pembuktian Surat Keterangan Waris yang Dibuat Ahli Waris dan Disah Kepala Desa/Lurah dan Camat
Dalam Surat Edaran Departemen Dalam

Negeri Direktorat Jenderal Agraria tanggal 20 Desember 1969 NomorDpt/12/63/12/69 tentang Surat Keterangan Warisan dan Pembuktian Kewarganegaraan disebutkan bahwa "surat keterangan waris untuk golongan penduduk asli dibuat oleh ahli waris, disaksikan oleh camat dan diketahui oleh camat."

Sedangkan dalam Pasal 111 ayat (1) huruf c angka 4 Peraturan Menteri Negara Agraria/Kepala Badan Pertanahan Nasional Nomor 3 Tahun 1997 tentang Pelaksanaan Peraturan Pemerintah Nomor 24 Tahun 1997 tentang Pendaftaran Tanah disebutkan "Bagi warga negara Indonesia penduduk asli: surat keterangan ahli waris yang dibuat oleh para ahli waris dengan disaksikan oleh 2 (dua) orang saksi dan dikuatkan oleh Kepala Desa/Kelurahan dan Camat tempat tinggal pewaris pada waktu meninggal dunia." Jelas terdapat perbedaan terhadap surat keterangan waris apabila Kepala Desa/Kelurahan dan Camat dapat menguatkan surat keterangan waris bukan hanya menyaksikan. Menguatkan berarti menambah unsur kekuatan terhadap surat keterangan waris sebagai suatu alat bukti perdata.

Alat bukti perdata diatur dalam Pasal 164 HIR, menurut Pasal 164 HIR alat-alat bukti terdiri dari bukti tulisan (surat), bukti dengan saksi, persangkaan, pengakuan dan sumpah. ${ }^{15}$ Dalam Pasal 165 HIR disebutkan bahwa: "Surat (akta) yang sah, ialah suatu surat yang diperbuat demikian oleh atau dihadapan pegawai umum yang berkuasa

\footnotetext{
14 Ronny Hanitijo, Kedudukan dan Tanggung Jawab Notaris dalam Pembuata Akta Autentik yang Mengandung Sengketa, Bina Cipta, Jakarta, 2011, hlm. 56

15 Retnowulan Sutanto, Hukum Acara Perdata dalam Teori dan Praktek, Mandar Maju, Bandung, 1997, hlm. 61
} 
untuk membuatnya, menjadi bukti yang cukup bagi kedua belah pihak dan ahli warisnya dan sekalian orang yang mendapatkan hak daripadanya tentang segala hal yang disebut di dalam surat itu dan juga tentang yang ada dalam surat itu sebagai pemberitahuan sahnya, dalam hal terakhir ini hanya jika yang diberitahukan itu berhubungan langsung dengan perihal pada surat (akta) itu."

Subekti mengatakan bahwa yang dimaksud dalam Pasal 165 HIR tersebut merupakan akta otentik yang merupakan alat bukti sempurna. Akta otentik memberikan diantara para pihak termasuk para ahli warisnya atau orang yang mendapat hak dari para pihak itu suatu bukti yang sempurna tentang apa yang dimuat di dalamnya. ${ }^{16}$ Habib Adjie menjelaskan kekuatan pembuktian sempurna yang terdapat dalam suatu akta otentik merupakan perpaduan dari beberapa kekuatan pembuktian dan persyaratan yang terdapat padanya.Dalam suatu akta otentik harus memenuhi kekuatan pembuktian lahir, formil dan materiil. ${ }^{17}$

Kehadiran ataupun kesaksian seorang pejabat umum terhadap suatu alat bukti sehingga dapat menambah kekuatan pembuktiannya dapat dikategorikan dalam unsur formal dari suatu akta. Yaitu mengenai formalitas akta, mengenai kebenaran apa yang dilihat, disaksikan dan didengar oleh seorang pejabat, juga mengenai kebenaran pernyataan ataupun keterangan para pihak yang disampaikan dihadapan pejabat yang berwenang. Tentunya tidaklah tepat apabila kepala desa, lurah dan camat dinilai dapat memberikan unsur formal tersebut terhadap surat keterangan waris, apabila mereka tidaklah memiliki kewenangan yang dimaksud yang diatur dalam suatu peraturan perundang-undangan.

3) Kekuatan Pembuktian Surat Keterangan Waris yang Dibuat Balai Harta Peninggalan

Balai harta peninggalan merupakan bagian dari struktur organisasi Departemen Hukum dan Hak Asasi Manusia, dibawah lingkungan Direktorat Perdata.Secara struktural tersebut maka BHP merupakan lembaga pemerintahan (eksekutif) yang melaksanakan urusan pemerintah. ${ }^{18}$ Pejabat tata usaha negara melaksanakan urusan pemerintahan dengan cara mengeluarkan keputusan-keputusan tata usaha negara, yang diatur dalam Pasal 1 ayat (3) Undang-Undang Nomor 5 Tahun 1986 tentang Peradilan Tata Usaha Negara. Surat keterangan waris sebagai suatu instrumen yang dapat membuktikan apakah seseorang adalah benar-benar ahli waris dari pewaris, merupakan suatu alat bukti dalam ranah bidang hukum perdata. Hal ini menjadi suatu ketidakjelasan apabila surat keterangan waris yang dikeluarkan oleh balai harta peninggalan menimbulkan suatu permasalahan, kemanakah surat keterangan waris yang merupakan penetapan dari balai harta peninggalan ini harus dipermasalahkan ataupun dibatalkan, apakah ke lingkungan peradilan tata usaha negara karena merupakan penetapan tertulis yang dikeluarkan oleh badan atau pejabat tata usaha negara, atau ke dalam lingkungan peradilan umum karena merupakan suatu alat bukti dalam ranah bidang hukum perdata.

16 R.Subekti, Hukum Pembuktian, Pradnya Paramita, Jakarta, 1978, hlm. 27

17 Habib Adjie, Sekilas Dunia Notaris \& PPAT Indonesia (Kumpulan Tulisan), Mandar Maju, Bandung, 2009, hlm. 62

18 I Gede Puwaka, Op., Cit, hlm. 11 


\subsection{Kepastian Hukum Pembuatan Keterangan}

Waris Berdasarkan Penggolongan Penduduk untuk Pengambilan Jaminan Kredit

Pasal 1 angka 2 Undang-Undang Nomor 12 Tahun 2011 tentang Pembentukan Peraturan Perundang-Undangan menyebutkan bahwa peraturan perundangundangan adalah: "Peraturan tertulis yang memuat norma hukum yang mengikat secara umum dan dibentuk atau ditetapkan oleh lembaga negara atau pejabat yang berwenang melalui prosedur yang ditetapkan dalam Peraturan Perundangundangan."

Adapun jenis peraturan perundangundangan diatur dalam Pasal 7 Ayat (1) UndangUndang Nomor 12 Tahun 2011 tentang Pembentukan Peraturan Perundang-Undangan dan dari enam macam jenis peraturan perundangundangan dalam pasal tersebut tidak termasuk surat keputusan menteri di dalamnya maupun peraturan menteri, maka Surat Edaran Departemen Dalam Negeri Direktorat Jenderal Agraria Tanggal 20 Desember 1969 nomor Dpt/12/63/12/69 tentang Surat Keterangan Warisan dan Pembuktian Kewarganegaraan maupun Peraturan Menteri Negara Agraria/Kepala Badan Pertanahan Nasional Nomor 3 Tahun 1997 tentang Pelaksanaan Peraturan Pemerintah Nomor 24 Tahun 1997 tentang Pendaftaran Tanah, bukanlah peraturan perundang undangan yang dimaksud dalam Pasal 15 Ayat (3) Undang-Undang Nomor 30 Tahun 2004 Juncto Undang-Undang Nomor 2 Tahun 2014 tentang Jabatan Notaris.
Suatu kewenangan haruslah bersumber dari suatu peraturan perundangundangan baik diperoleh dengan cara atribusi, delegasi ataupun mandat. Hal ini sesuai dengan pendapat dari R.J.H.M. Huisman, bahwa kewenangan hanya diberikan oleh undang-undang: "Pembuat undangundang dapat memberikan wewenang pemerintahan tidak hanya kepada organ pemerintahan, tetapi juga terhadap para pegawai atau terhadap badan khusus atau bahkan badan hukum privat. ${ }^{19}$ Setiap perbuatan pemerintahan diisyaratkan harus bertumpu atas kewenangan yang sah. Kewenangan yang sah adalah kewenangan yang berdasarkan pada suatu undang-undang. Hal ini merupakan suatu asas legalitas. Asas legalitas merupakan dasar dalam setiap penyelenggaraan kenegaraan dan pemerintahan. Setiap penyelenggaraan kenegaraan dan pemerintahan harus memiliki legitimasi, yaitu kewenangan yang diberikan oleh undang-undang."20 Dengan demikian, maka sampai saat ini kewenangan notaris dalam membuat surat keterangan waris tidaklah dilandasi oleh suatu peraturan perundang-undangan. Suatu tindakan pejabat umum untuk membuat alat bukti keperdataan seseorang yang didalamnya menerangkan tentang siapa saja yang berhak atas suatu harta warisan yang terbuka, beserta berapa saja bagianbagiannya. Namun merupakan tindakan yang tidak sesuai dengan asas legalitas.

Pembuatan keterangan hak waris oleh seorang Notaris bagi orang-orang yang tunduk pada Kitab Undang-Undang Hukum Perdata tidak ada

19 Ridwan HR, Hukum Administrasi Negara, Rajagrafindo Persada, Jakarta, 2006, hlm. 103

20 lbid., hlm. 100 
dasar hukumnya dalam hukum tertulis yang berlaku di Indonesia.. ${ }^{21}$ Dengan demikian, selama ini surat keterangan waris untuk etnis/golongan penduduk eropa, cina/tiongha, timur asing (kecuali orang arab yang beragama islam) tidak mempunyai landasan hukum (berdasarkan hukum positif) sama sekali, tetapi tindakan hukum tersebut hanya merupakan kebiasaan Notaris sebelumnya yang kemudian diikuti oleh Notaris berikutnya apa adanya, tanpa mengkaji lebih jauh kewenangan Notaris untuk membuat Surat Keterangan Waris. Bahkan tindakan Notaris seperti itu dapat dikualifikasikan sebagai tindakan di luar wewenang Notaris.

Sebagai contoh praktik di lapangan, walaupun ada ketentuan bagi penduduk pribumi cukup menggunakan Surat Keterangan Waris yang dibuat di bawah tangan, namun kenyataannya seringkali pihak yang berkepentingan meminta Surat Keterangan Waris tersebut dibuat oleh Notaris. Hal ini seperti ketentuan yang berlaku di Bank CIMB Niaga bahwa persyaratan pengambilan jaminan lunas kredit diatur sebagai berikut:

1. Debitur langsung: (a) asli KTP, atau (2) asli passport dan KITAP/KITAS asli (WNA);

2. Surat Kuasi Notaril: (a) asli Surat Kuasa Akta Notaril; (b) asli KTP/passport pemberi kuasa atau copy legalisir notaris; (c) asli KTP/passport penerima kuasa;

3. Surat Kuasa Debitur Domisili di Luar Negeri: (a) asli Surat Kuasa yang dibuat di hadapan Public Notary; (b) asli Surat Kuasa legalisir dari Kedusbes/Konjen; (c) copy KTP/passport pemberi kuasa legalisir Kedusbes/Konjen/Notaris; $\quad$ (d) asli KTP/passport pemberi kuasa;
4. Debitur meninggal: (a) asli KTP/passport debitur (jika ada); (b) asli KTP/passport para ahli waris; (c) asli Kartu Keluarga; (d) asli KITAP/KITAS (WNA); (e) asli Akta Kelahiran; (f) asli Surat Kematian debitur; (g) asli Surak Nikah; (h) asli Surat Cerai (kondisi khusus); (i) asli Akta Waris Debitur; (j) asli Surat Kuasa Ahli Waris (Notaril); (k) asli Surat Pernyataan Ahli Waris (standar bank).

Sesuai ketentuan angka 4 huruf (j) di atas bahwa Surat Kuasa Ahlli Waris atau Surat Keterangan Waris untuk mengambil jaminan kredit di Bank CIMB Niaga harus dibuat oleh Notaris. Praktik seperti ini, dilihat dari ketentuan hukum yang berlaku di Indonesia jelas bertentangan dengan surat Mahkamah Agung Republik Indonesia tanggal 8 Mei 1991 Nomor MA/Kumdil/171/V/K/1991 tentang Surat Keterangan Waris harus diterbitkan berdasarkan penggolangan penduduk, untuk golongan pribumi cukup dibuat oleh RT, RW, Kelurahan hingga Kecamatan.

Wewenang notaris membuat Surat Keterangan Waris tidak disebutkan dalam Undang-undang Nomor 2 Tahun 2014 tentang Jabatan Notaris karena UUJN hanya mengatur tentang wewenang Notaris membuat akta otentik. Wewenang Notaris membuat Surat Keterangan Waris tidak disebutkan dengan jelas dalam UUJN, karena sejak jaman dahulu Surat Keterangan Waris seringkali dibuat oleh notaris, sehingga dasar pembuatan Surat Keterangan Waris oleh notaris adalah hukum kebiasaan yang berlaku selama ini dibidang

21 Ting Swan Tiong, Pembuktian Hak Atas Harta Peninggalan, Media Notariat Nomor 6-7, April 1988, hlm. 115. 
notariat.

Mengatasi tumpang tindihnya peraturan perundang-undangan yang berhak/berwenang membuat bukti (formalitas) sebagai ahli waris dan pejabat/institusi yang membuatnya dan menimbulkan kerancuan dan berkesan diskriminatif dan dalam rangka perlunya kepastian hukum yang bersifat demokratis dan berkeadilan, maka perlu ditentukan satu bentuk fomalitas bukti sebagai ahli waris dan satusatunya institusi atau pejabat yang berwenang membuatnya, sehingga tercipta kepastian hukum.

Menurut Van Kan kepastian hukum adalah hukum bertugas menjamin adanya kepastian hukum dalam pergaulan manusia. ${ }^{22}$ Lebih lanjut Van Kan menyatakan: ${ }^{23}$ kepastian hukum adalah perangkat hukum suatu negara yang mampu menjamin hak dan kewajiban setiap warga negara. Kepastian hukum tersebut dibedakan dalam dua macam yaitu: 1) kepastian oleh karena hukum, yaitu hukum menjamin kepastian antara pihak yang satu terhadap pihak yang lainnya, artinya adanya konsistensi penerapan hukum kepada semua orang tanpa pandang bulu, dan, 2) kepastian dalam atau dari hukum, artinya kepastian hukum tercapai jika hukum itu sebanyakbanyaknya undang-undang, tidak ada ketentuan yang bertentangan (undang-undang berdasarkan sistem logis dan pasti), dibuat berdasarkan kenyataan hukum (rechtswerkelijkheid) dan di dalamnya tidak ada istilah yang dapat ditafsirkan secara berlain-lainan (tertutup).

\subsection{Perlunya Pembaharuan Hukum Pembuatan}

Keterangan Waris Tanpa Deskriminasi Ras dan Etnik

Latar belakang pemerintahan Belanda memberlakukan penggolongan penduduk di Indonesia adalah menjalankan politik devide et impera atau politik pemecah belah. Politik devide et impera ini dilakukan dengan cara membagi penduduk nusantara dalam 3 (tiga) golongan penduduk yaitu: Golongan Eropa, Golongan Timur Asing (seperti Tionghoa, India, Arab, Pakistan), dan Golongan Pribumi, sebagaimana diatur dalam Pasal 163 IS.

Adanya pemisahan penduduk dengan golongan-golongan penduduk yang didasarkan pada etnis atau ras dalam Pasal 163 IS ini berakibat pada bedanya sistem hukum yang diberlakukan terhadap setiap golongan tersebut. Tiga golongan penduduk tersebut tunduk pada hukum perdata yang berbedabeda sebagaimana diatur dalam Pasal 131 IS. Dengan demikian, pembuatan surat keterangan waris berdasarkan golongan penduduk Indonesia tersebut sebenarnya sudah tidak sesuai dengan keadaan sekarang di Indonesia, apalagi setelah diberlakukannya Undang-Undang Nomor 12 Tahun 2006 tentang Kewarganegaraan Republik Indonesia, yang di dalam Pasal 2 menyebutkan: "Yang menjadi Warga Negara Indonesia adalah orang-orang bangsa Indonesia asli dan orang-orang bangsa lain yang disahkan dengan undang-undang sebagai warga negara". Penyebutan seseorang adalah bangsa Indonesia asli menurut Pasal 2

22 E. Utrecht dan Moh. Saleh J. Jindang, Pengantar Dalam Hukum Indonesia, Iktiar Baru dan Sinar Harapan, Jakarta, 1989, hlm. 25.

23 E. Fernando M. Manullang, Menggapai Hukum Berkeadilan Tinjauan Hukum Kodrat dan Antinomi Nilai, PT. Kompas Media Nusantara, Jakarta, 2007, hlm. 92. 
Penjelasan Atas Undang-Undang Nomor 12 Tahun 2006 tentang Kewarganegaraan Republik Indonesia: "Yang dimaksud dengan "orang-orang bangsa Indonesia asli" adalah orang Indonesia yang menjadi Warga Negara Indonesia sejak kelahirannya dan tidak pernah menerima kewarganegaraan lain atas kehendak sendiri",

Di samping itu, juga telah diberlakukan pula Undang-Undang Nomor 40 Tahun 2008 tentang Penghapusan Golongan Ras Dan Etnis. Pasal 1 angka (1) menyebutkan bahwa "Diskriminasi ras dan etnis adalah segala bentuk pembedaan, pengecualian, pembatasan, atau pemilihan berdasarkan pada ras dan etnis, yang mengakibatkan pencabutan atau pengurangan pengakuan, perolehan, atau pelaksanaan hak asasi manusia dan kebebasan dasar dalam suatu kesetaraan di bidang sipil, politik, ekonomi, sosial, dan budaya"

Pasal 5 UU Nomor 40 Tahun 2008 menyebutkan bahwa penghapusan diskriminasi ras dan etnis wajib dilakukan dengan memberikan:

a. perlindungan, kepastian, dan kesamaan kedudukan di dalam hukum kepada semua warga negara untuk hidup bebas dari diskriminasi ras dan etnis;

b. jaminan tidak adanya hambatan bagi prakarsa perseorangan, kelompok orang, atau lembaga yang membutuhkan perlindungan dan jaminan kesamaan penggunaan hak sebagai warga negara; dan c. pemahaman kepada masyarakat mengenai pentingnya pluralisme dan penghargaan hak asasi manusia melalui penyelenggaraan pendidikan nasional.

Setiap manusia berkedudukan sama di hadapan Tuhan Yang Maha Esa karena dilahirkan dengan martabat, derajat, hak dan kewajiban yang sama. Pada dasarnya, manusia diciptakan dalam kelompok ras atau etnis yang berbeda-beda yang merupakan hak absolut dan tertinggi dari Tuhan Yang Maha Esa. Dengan demikian, manusia tidak bisa memilih untuk dilahirkan sebagai bagian dari ras atau etnis tertentu. Adanya perbedaan ras dan etnis tidak berakibat menimbulkan perbedaan hak dan kewajiban antar-kelompok ras dan etnis dalam masyarakat dan negara.

Kondisi masyarakat Indonesia, yang berdimensi majemuk dalam berbagai sendi kehidupan, seperti budaya, agama, ras dan etnis, berpotensi menimbulkan konflik. Ciri budaya gotong royong yang telah dimiliki masyarakat Indonesia dan adanya perilaku musyawarah/mufakat, bukanlah jaminan untuk tidak terjadinya konflik, terutama dengan adanya tindakan diskriminasi ras dan etnis.

Menanggapi adanya perbedaan penggolongan penduduk tersebut, Soepomo menjelaskan pentingnya menentukan kewarganegaraan agar tidak ada konflik dari sudut hukum, selain itu Soepomo menyatakan bahwa "bangsa ini yang menjadi warga Negara dan sudah tentu jikalau sudah tetap dalam Negara merdeka, ini menjadi warga Negara, dengan sendirinya status dulu hilang". Akhirnya Soepomo menyimpulkan, bahwa pengaturan kewarganegaraan tidak perlu dimasukan dalam UUD, tetapi penting untuk diatur 
dalam undang-undang, maka lahirlah Pasal 26 dalam Undang-Undang Dasar Tahun 1945, yang menyatakan bahwa (1) Yang menjadi warga Negara Indonesia ialah orang-orang Indonesia asli dan orang-orang bangsa lain yang disahkan UndangUndang sebagai warga Negara. (2) Syarat-syarat yang mengenai kewarganegaraan ditetapkan Undang-Undang. Atas lahirnya Pasal 26 UUD 1945 tersebut, penggolongan penduduk Indonesia berdasarkan Pasal 163 IS (Indische Staatsregeling) yang membagi penduduk Indonesia (Hindia Belanda) dalam tiga golongan dan Pasal 131 I.S. yang menentukan hukum apa yang berlaku untuk masing-masing golongan penduduk tersebut, sudah tidak relevan berdasarkan sudut hukum tata Negara. ${ }^{24}$

Dalam rangka pengamalan Pancasila dan pelaksanaan Undang-Undang Dasar Negara Republik Indonesia Tahun 1945, Indonesia pada dasarnya telah menetapkan peraturan perundangundangan yang mengandung ketentuan tentang penghapusan segala bentuk diskriminasi ras dan etnis, tetapi masih belum memadai untuk mencegah, mengatasi, dan menghilangkan praktik diskriminasi ras dan etnis dalam suatu undang-undang.

Penghapusan pembedaan golongan penduduk juga secara tegas diatur dalam Pasal 27 ayat (1) UUD 1945 yang menyatakan: Setiap warga negara bersamaan dalam kedudukannya di dalam hukum dan pemerintahan dan wajib menjunjung hukum dan pemerintahan itu dengan tidak ada kecualinya. Pasal 28 D ayat (1) menyatakan: Setiap orang berhak atas pengakuan, jaminan, perlindungan dan kepastian hukum yang adil serta perlakuan yang sama di hadapan hukum. Penghapusan penggolongan penduduk ini kemudian diatur lebih lanjut melalui Undang-Undang Nomor 12 Tahun 2006 tentang Kewarganegaraan Republik Indonesia. Dalam Pasal 2 jo Pasal 4 ditentukan bahwa Warga Negara Indonesia adalah orang-orang bangsa Indonesia asli dan orang-orang bangsa lain yang disahkan dengan Undang-Undang sebagai Warga Negara Indonesia. Dalam penjelasan Pasal 2 UU kewarganegaraan disebutkan yang dimaksud dengan "orang-orang bangsa Indonesia asli" adalah orang Indonesia yang menjadi Warga Negara Indonesia sejak kelahirannya dan tidak pernah menerima kewarganegaraan lain atas kehendak sendiri.

Pasal 28 I ayat 2 UUD RI 1945, "Setiap orang berhak bebas atas perlakuan yang bersifat diskriminatif atas dasar apapun dan berhak mendapatkan perlindungan terhadap perlakuan yang bersifat diskriminatif". Diskriminasi merupakan tindakan yang menjadi permasalahan hukum dan Hak Asasi Manusia, HAM sebagai nilai dan/atau norma menjamin dan mengakui bahwa setiap orang berhak menikmati hak-hak dan kebebasan dasar yang melekat pada hakekat dan keberadaan manusia. Pasal 2 ayat 1 Bab II Asas Dan Tujuan dalam Undang-Undang Nomor 40 Tahun 2008 menegaskan bahwa Penghapusan diskriminasi ras dan etnis dilaksanakan berdasarkan asas persamaan, kebebasan, keadilan, dan nilai-nilai kemanusiaan yang universal.

Diskriminasi rasial dalam pembuatan surat keterangan waris, bertentangan dengan semangat pembangunan negara demokrasi (natio bulding), bahwa dengan adanya penggolongan penduduk -

24 Muhammad Rijal, "Tidak ada Pribumi, Timur Asing dan Eropa", tersedia di: http://rijal-akay.blogspot.com/2017/03/tidakada-pribumi-timur-asing-dan-eropa.html?m=1 
34 Aden Ahmad dkk, Kepastian Hukum Surat Keterangan Waris.....

khususnya dalam pembuatan surat keterangan waris, terjadi sebuah tindakan dan/atau kebijakan yang bertentangan dengan hukum yakni Undangundang Nomor 40 Tahun 2008 tentang Penghapusan Diskriminasi Ras dan Etnis berupa tindakan pembedaan dan/atau pembatasan bagi golongangolongan tertentu untuk memperoleh kebebasan dasar dan/atau pelaksanaan hak asasi manusia berupa kebutuhannya untuk memperoleh alat bukti otentik yang menerangkan dirinya sebagai pihak yang berhak atas harta warisan yang ditinggalkan untuknya.

Berdasarkan UU Nomor 8 Tahun 2008 di atas, maka penggolongan penduduk dan hukum yang berlaku untuk setiap golongan penduduk tersebut seharusnya sudah tidak ada lagi, tetapi dalam kenyataannya masih diberlakukan, antara lain telah dijadikan dasar hukum dalam pembentukan aturan hukum yang berlaku setelah Indonesia merdeka untuk pembuatan bukti sebagai ahli waris.

Pemberlakuan ketentuan ini merupakan tindakan dikriminatif sekaligus rasialis, dan melanggar prinsip-prinsip Hak Azasi Manusia. Dengan demikian, aturan hukum dalam pembuatan bukti sebagai ahli waris yang masih harus berdasarkan etnis dan institusi yang membuatnya berbeda harus segera diakhiri, di samping itu tidak ada akibat hukum apapun dengan adanya pembedaan bukti ahli waris berdasarkan etnis.

Untuk menghilangkan dan menghapuskan dikriminasi dalam bentuk formal dan pejabat/instusi yang membuat bukti ahli waris untuk Warga Negara Indonesai, maka Notaris dapat berperan sebagai satu-satunya pihak yang dapat membuat bukti sebagai ahli waris. Sebagai Notaris yang hidup dalam sebuah Negara merdeka, notaris harus secara aktif ikut serta mengimplementasikan nilai-nilai kemerdekaan dalam suatu tindakan nyata. Notaris harus siap menjadi agen pembaharuan dan satusatunya pejabat yang berwenang untu membuat bukti ahli waris dalam bentuk (formal) akta pihak untuk seluruh Warga Negara Indonesai, tanpa bedasarkan golongan/etnis/suku ataupun agama. Dengan demikian Notaris harus memposisikan dirinya sebagai pejabat yang hadir untuk melayani kepentingan masyarakat. Notaris bukan sebagai pelayan yang baik, jika ternyata masih membawa visi dan misi Kolonial, yaitu masih ingin membuat, mempertahankan dan melakukan tindakan hukum diskriminatif, khususnya dalam pembuatan bukti ahli waris. Notaris seharusnya memposisikan diri dengan mengimplementasikan wewenang Notaris sebagai Pejabat yang berwenang untuk membuat bukti ahli waris untuk semua masyarakat Indonesia, tidak berdasarkan etnis dan golongan apapun dalam bentuk formal akta pihak.

Dasar hukum bahwa Notaris dapat menjadi satu-satunya Pejabat/institusi yang berwenang untuk membuat bukti ahli waris untuk semua masyarakat Indonesia, tidak berdasarkan etnis dan golongan, agama apapun, yaitu berdasarkan kewenang Notaris yang tersebut dalam Pasal 15 ayat (1) Undangundang Jabatan Notaris (UUJN), yaitu membuat akta. Dengan kehadiran UUJN tersebut saat ini merupakan satu-satunya undang-undang yang mengatur Notaris Indonesia, yang berarti telah terjadi unifikasi hukum dalam bidang pengaturan Notaris. Hal ini sesuai pendapat Herlian Budiono, yang mengatakan atas dasar ketentuan - 
Pasal 15 ayat (1), Notaris berwenang untuk membuat KHW dalam bentuk akta otentik tidak saja bagi mereka yang tunduk pada KUHPerdata, tetapi juga bagi seluruh bangsa Indonesia. ${ }^{25}$

\section{Simpulan}

Adanya ketentuan penggolongan penduduk seperti ketentuan Pasal 131 dan 163 Indische Staatregeling tidak dapat memberikan kepastian hukum dalam pembuatan keterangan waris yang digunakan sebagai syarat pengambilan jaminan kredit, karena dalam praktiknya ada pihak bank yang meminta surat keterangan waris harus dibuat oleh Notaris walaupun yang bersangkutan termasuk golongan pribumi. Walaupun sebenarnya Pasal 15 ayat (1) UUJN 2014 tidak secara jelas menyebutkan kewenangan Notaris untuk membuat surat keterangan waris, namun pihak bank lebih memilih surat keterangan waris harus dibuat oleh Notaris, dengan pertimbangan karena surat keterangan waris yang dibuat oleh Notaris lebih memiliki kekuatan pembuktian yang kuat, karena setiap akta yang dibuat oleh Notaris memiliki kekuatan pembuktian lahiriah, formal dan material. Perlu diperhatikan bahwa setelah Indonesia Merdeka, mestinya praktik pembuatan surat keterangan waris berdasarkan golongan pendudukan tidak perlu ada lagi, karena hal tersebut bertentangan dengan UU Nomor 40 Tahun 2008, karena hal tersebut merupakan tindakan dikriminatif sekaligus rasialis, dan melanggar prinsip-prinsip Hak Azasi Manusia. Dengan demikian, aturan hukum dalam pembuatan bukti sebagai ahli waris yang masih harus berdasarkan etnis dan institusi yang membuatnya berbeda harus segera diakhiri, di samping itu tidak ada akibat hukum apapun dengan adanya pembedaan bukti ahli waris berdasarkan etnis.

\section{DAFTAR PUSTAKA}

Adjie, Habib. Sekilas Dunia Notaris \& PPAT Indonesia (Kumpulan Tulisan). Bandung: Mandar Maju, 2009.

Ali, Zainuddin. Pelaksanaan Surat Keterangan Hak Waris bagi Golongan Penduduk di Indonesia, Jakarta: Sinar Grafika, 2011.

Budiono, Herlien. Kumpulan Tulisan Hukum Perdata di Bidang Kenotariatan, Buku Kedua. Bandung: Citra Aditnya Bakti, 2013.

Djumhana, Muhamad. Hukum Perbankan di Indonesia. Bandung: Citra Aditya Bakti, 1993.

Hanitijo, Ronny. Kedudukan dan Tanggung Jawab Notaris dalam Pembuata Akta Autentik yang
Mengandung Sengketa. Jakarta: Bina Cipta, 2011.

HR, Ridwan. Hukum Administrasi Negara. Jakarta: Rajagrafindo Persada, 2006.

Manullang, E. Fernando M. Menggapai Hukum Berkeadilan Tinjauan Hukum Kodrat dan Antinomi Nilai. Jakarta: Kompas Media Nusantara, 2007.

Purwaka, I Gede. Keterangan Hak Mewarisi Yang Dibuat Oleh Notaris Berdasarkan Ketentuan Kitab Undang-Undang Hukum Perdata (Burgerljik wetboek). Jakarta: Program Spesialis Notariat Dan Pertahanan Fakultas Hukum Universitas Indonesia, 1999.

25 Herlien Budiono, Op.Cit., hlm. 100 
36 Aden Ahmad dkk, Kepastian Hukum Surat Keterangan Waris.....

Soekanto, Soerjono. Hukum Adat Indonesia. Jakarta: Rajawali, 1981.

Subekti, R. Hukum Pembuktian. Jakarta: Pradnya Paramita, 1978.

Sugiono, Akta Autentik Notaris, Suatu Tinjauan Yuridis dan Praktis, Bandung: Balei, 2008.

Sutanto, Retnowulan. Hukum Acara Perdata dalam Teori dan Praktek, Bandung: Mandar Maju, 1997.

Tiong, Ting Swan. Pembuktian Hak Atas Harta Peninggalan, Media Notariat Nomor 6-7, April 1988
Utrecht, E dan Moh. Saleh J. Jindang. Pengantar Dalam Hukum Indonesia. Jakarta: Iktiar Baru dan Sinar Harapan, 1989.

Yani, Ahmad \&Gunawan Wijaya. Seri Hukum Bisnis/Jaminan Fidusia. Jakarta: Radja Grailndo Perkasa, 2000.

HYPERLINK "http://rijal-akay.blogspot.com/?m=1" Muhammad Rijal , "Tidak ada Pribumi, Timur Asing dan Eropa", tersedia di: http://rijalakay.blogspot.com/2017/03/tidak-adapribumi-timur-asing-dan-eropa.html?m=1 